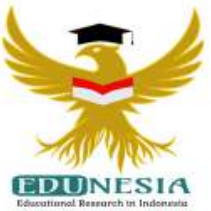

\title{
Persepsi Mahasiswa Terhadap Atribut Pembelajaran Sistem Daring Online Pada Mata Kuliah Matematika Di STIENI Jakarta
}

\author{
Gary Yefta Herbeth Siagian \\ Manajemen, Sekolah Tinggi Ilmu Ekonomi Nasional Indonesia, Indonesia \\ Corresponding Email: garyyeftanew02@yahoo.com, Phone Number : 0858 xxxx xxxx
}

\author{
Article History: \\ Received: Juli 13, 2020 \\ Revised: Juli 19, 2020 \\ Accepted: Sept 02, 2020 \\ Published: Nov 01, 2020
}

\section{Keywords:}

Learning system online, Mathematics

Perception Students,

Kata Kunci:

Matematika,

Persepsi Mahasiswa,

Pembelajaran Sistem daring,

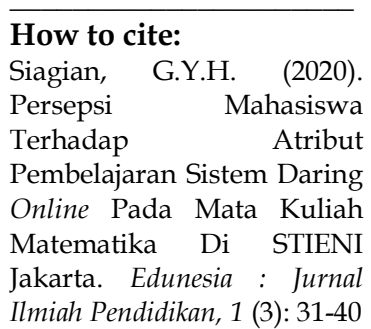

This is an open access article under the CC-BY-NC-ND license cc) (i) $(-)$

\begin{abstract}
Covid-19 is a dangerous disease that attacks the throat system in humans with a very rapid spread of transmission. Various appropriate ways to respond to government proposals in breaking the distribution chain of co-19. One of the ways the government attempts to break the chain of distribution of covid-19 in the world of education is by engaging in remote interactions with online systems. The purpose of the study was to analyze the perceptions and levels of student satisfaction with online system attributes in mathematics courses at STIENI Jakarta. The sampling process in this study was purposive sampling. Data collection techniques using a survey method using a sample of 25 respondents. This study uses the Friedman Test analysis, and the Customer Satisfaction Index (CSI). The results showed for online online system attributes that the first rank of students assessed a learning method of 3.52, for the second position was service in learning by 3.48 , and for the last rank was the quality of learning and education personnel by 1.50. For the level of satisfaction, students rated online online system attributes as quite satisfied by $65 \%$.
\end{abstract}

Abstrak: Covid-19 merupakan suatu penyakit berbahaya yang menyerang sistem tenggorokan pada manusia dengan penyebaran penularan sangat cepat. Berbagai cara yang tepat dalam menanggapi usulan pemerintah dalam memutuskan rantai penyebaran covid-19. Salah satu cara upaya pemerintah dalam memutus rantai penyebaran covid-19 dalam dunia pendidikan adalah dengan melakukan hubungan interaksi secara jauh dengan sistem daring secara online. Tujuan penelitian adalah untuk menganalisis persepsi dan tingkat kepuasan mahasiswa terhadap atribut sistem daring secara online pada mata kuliah matematika di STIENI Jakarta. Proses pengambilan sampel dalam penelitian ini secara purposive sampling. Teknik pengumpulan data dengan menggunakan metode survei dengan menggunakan sampel 25 responden. Penelitian ini menggunakan analisis Uji Friedman, dan Customer Satisfaction Indeks (CSI). Hasil penelitian menunjukkan untuk atribut sistem daring online adalah peringkat pertama mahasiswa menilai metode pembelajaran sebesar 3,52, untuk posisi kedua adalah pelayanan dalam pembelajaran sebesar 3,48, dan untuk peringkat terakhir adalah kualitas pembelajaran dan tenaga kependidikan sebesar 1,50. Untuk tingkat kepuasan, mahasiswa menilai atribut sistem daring online adalah cukup puas sebesar $65 \%$. 


\section{A. Pendahuluan}

Pada akhir tahun 2019, dunia digemparkan dengan munculnya virus yang mematikan yang bernama Covid-19. Covid-19 merupakan virus yang menyebaran penyakit sangat cepat dan menyerang sistem pernafasan pada manusia. Salah satu Negara yang mengalami pertumbuhan peningkatan penyebaran Covid-19 secara signifikan adalah Indonesia. Di Indonesia pada Bulan Maret 2020-Mei 2020, tercatat mengalami peningkatan kasus yang menderita virus covid-19 sekitar 1528 kasus pada bulan Maret, Bulan April 10.118 kasus, serta Bulan Mei sebesar 26.473 kasus (Youtube kompasTV, 2020). Provinsi yang terbanyak mengalami peningkatan penyebaran Covid-19 di Pulau Jawa adalah DKI Jakarta. Pada tabel 1. menunjukkan DKI Jakarta merupakan jumlah penyebaran terbanyak di Pulau Jawa dari bulan Maret 2020-Mei 2020.

Tabel 1.

Data Penyebaran Covid-19 di Pulau Jawa Pada Bulan Maret 2020-Mei 2020

\begin{tabular}{clccc}
\hline & & \multicolumn{3}{c}{ Keterangan (kasus) } \\
\cline { 3 - 5 } No. & Provinsi & Maret & April & Mei \\
\hline 1. & Banten & 142 & 346 & 861 \\
\hline 2. & DKI Jakarta & 747 & 4.138 & 7.272 \\
\hline 3. & Jawa Barat & 198 & 1.009 & 2.260 \\
\hline 4. & Jawa Tengah & 93 & 730 & 1.403 \\
\hline 5. & Jawa Timur & 93 & 951 & 4.857 \\
\hline Total & & 1.273 & 7.174 & 16.653 \\
\hline
\end{tabular}

Sumber : Youtube kompasTV, (2020)

Salah satu cara dalam memutus rantai penyebaran yang dilakukan oleh pemerintah adalah dengan melakukan Pembatasan Sosial Berskala Besar (PSBB). PSBB merupakan aturan kebijakan program pemerintah dalam memutuskan rantai penyebaran covid-19 seperti pembatasan aktivitas sekolah dan bekerja. Salah satu cara pembatasan aktivitas sekolah adalah dengan melakukan pembelajaran jarak jauh secara online. Pembelajaran jarak jauh secara online merupakan pembelajaran individu/mandiri atau kelompok menggunakan Teknologi Informasi, dan Komunikasi (TIK) dan jejaring (Pannen, 2016).

Pembelajaran jarak jauh secara online dalam pelaksanaannya memerlukan perangkat-perangkat mobile seperti handphone, dan laptop dalam mengakses (Gikas dan Grant, 2013). Pembelajaran sistem daring secara online dapat memungkinkan mahasiswa untuk menghadiri perkuliahan dari rumah masing-masing.

Matematika merupakan ilmu eksakta yang banyak menggunakan rumus-rumus dalam perhitungan. Dimana dalam mengerjaannya, matematika harus dipelajari secara tatap muka langsung dengan menggunakan alat seperti whiteboard, laptop, penggaris, dan lain sebagainya agar ilmu dapat yang tersampaikan dengan baik.

Oleh sebab itu, untuk pencapaian dalam mempelajari ilmu matematika, dilakukan dengan sikap dalam sistem pembangunan yang efektif, Aktif dan inovatif dalam metode pembelajaran matematika (Siagian, 2016). Persepsi merupakan suatu pandangan manusia tentang segala sesuatu yang dilihat, diraba dan dirasakan sehingga timbul pemikiran baik maupun buruk. Persepsi merupakan suatu hal yang diterima berupa pesan dan informasi yang masuk yang ada didalam otak manusia (Slamento, 2003). Kepuasan merupakan 
suatu bentuk hasil yang timbul dari sikap puas dan kecewa terhadap suatu yang dirasakan.

Penelitian ini menganalisis persepsi dan tingkat kepuasan mahasiswa terhadap atribut sistem daring secara online pada mata kuliah matematika di STIENI Jakarta.

\section{B. Metode}

Penelitian dilaksanakan pada bulan Mei-Juni 2020. Penelitian ini menggunakan jenis penelitian kualitatif pada populasi Mahasiswa Sekolah Tinggi Ilmu Ekonomi Nasional (STIENI) Jakarta Timur. Responden penelitian ini adalah para mahasiswa STIENI yang mengampuh mata kuliah matematika. Teknik pengambilan sampel secara purposive sampling. Pengumpulan data di lapangan menggunakan kuesioner dengan teknik survei. Data yang digunakan adalah data primer dengan berpedoman pada kuisioner dan sekunder seperti jurnal, skripsi dan tesis serta literature lainnya yang mendukung dalam proses penulisan. Skala pengukuran menggunakan skala likert pada rentang nilai sangat penting dengan skor 5 sampai dan sangat tidak penting dengan skor 1. Variabel kualitas dalam pembelajaran memiliki empat item pernyataan, variabel model pembelajaran memiliki lima item pernyataan. Untuk variabel tenaga pendidikan memiliki empat item pernyataan, serta pelayanan dalam pembelajaran memiliki lima item pernyataan.

\section{Metode Analisis Data}

Teknik analisis data menggunakan analisis deskriptif, uji friedman dan Customer Satisfaction Indeks (CSI). Analisis deskriptif menjelaskan karakteristik responden dengan menggunakan Microsoft excel 2010. Untuk analisis persepsi mahasiswa terhadap atribut sistem daring secara online menggunakan pemgujian uji friedman dengan Statistical Package for the Social Science (SPSS) versi 16,00. Pada uji Friedman, menggunakan rumus berikut :

$x_{r}^{2}=\frac{12 \sum\left(R_{j}\right)^{2}-3 N^{2} k(k+1)^{2}}{N K x(k+1)+\frac{N k-T}{k-1}}$,

dimana : $\mathrm{N}=$ Banyaknya kelompok, $\mathrm{k}=$ banyaknya perlakuan, $\mathrm{R}=$ jumlah ranking perlakuan (Riadi, 2016).

Untuk mengukur tingkat kepuasan mahasiswa terhadap atribut pembelajaran sistem daring online menggunakan Metode Customer Satisfaction Indeks (CSI) (Dickson et al, 2004). Ada empat langkah dalam menghitung indeks kepuasan mahasiswa terhadap pembelajaran sistem daring secara online yaitu :

1. Menentukan Mean Satisfaction Score (MSS) dan Mean Important Score (MIS). Nilai ini berasal dari rata-rata tingkat kepuasan tenaga pendidikan dan tingkat kepentingan mahasiswa setiap responden terhadap masing-masing variabel. Rumusnya yaitu : MSS $=\frac{\sum_{i=1}^{n} X i}{n}$ dan MIS $=\frac{\sum_{i=1}^{n} Y i}{n}$, dengan keterangan $:$ MSS = nilai rata-rata tingkat kepuasan tenaga pendidikan, MIS = nilai rata-rata tingkat kepentingan mahasiswa, $\mathrm{n}=$ jumlah sampel, $\mathrm{Xi}=$ nilai tingkat kepuasan tenaga pendidikan variabel $\mathrm{ke}-\mathrm{i}, \mathrm{Yi}=$ nilai tingkat kepentingan mahasiswa variabel ke-i. 
2. Menghitung Weight Factors (WF). Bobot ini merupakan persentasi nilai MIS dari setiap variabel terhadap total MIS seluruh variabel. Rumusnya yaitu $: \mathrm{WF}=\frac{M I S}{\Sigma_{i=1}^{p} \text { MIS }}$.

3. Menghitung Weight Score (WS). Bobot ini merupakan perkalian antara weight factors dengan rata-rata tingkat kinerja tenaga pendidikan (Mean Satisfaction Score = MSS). Rumusnya yaitu: WS = WF x MSS.

4. Menentukan Customer Satisfaction Indeks (CSI). Rumusnya yaitu : CSI $=\frac{\Sigma_{i=1}^{p} w s}{n} \times 100 \%$. Kemudian hasil dari perhitungan dari customer satisfaction indeks dimasukkan ke dalam kriteria skala kepuasan mahasiswa. Skala kepuasan mahasiswa yang umumnya dipakai untuk menginterpretasikan indeks dapat dilihat pada tabel 2.

Tabel 2.

Kriteria Tingkat Kepuasan

\begin{tabular}{|c|c|}
\hline Nilai CSI (\%) & Keterangan \\
\hline $81 \%-100 \%$ & Sangat puas \\
\hline $66 \%-80,99 \%$ & Puas \\
\hline $51 \%-65,99 \%$ & Cukup puas \\
\hline $35-50,99 \%$ & Kurang puas \\
\hline $0-34,99 \%$ & Tidak puas \\
\hline
\end{tabular}

Sumber : Widodo dan Joko (2018)

\section{Hasil dan Pembahasan}

\section{Keadaan Umum Responden}

Pengumpulan data menggunakan kuesioner terhadap mahasiswa STIENI di Jakarta Timur yang mengampuh mata kuliah matematika sebanyak 25 kuesioner. Berikut ini adalah karakter responden.

\section{Tabel 3.}

Karakteristik Responden

\begin{tabular}{|c|c|c|c|}
\hline No & Karakteristik Responden & $\begin{array}{c}\text { Jumlah } \\
\text { (kampus) }\end{array}$ & $\begin{array}{c}\text { Persentase } \\
(\%)\end{array}$ \\
\hline \multirow[t]{3}{*}{1.} & Jenis Kelamin & & \\
\hline & Laki-laki & 13 & 52 \\
\hline & Perempuan & 12 & 48 \\
\hline \multirow[t]{4}{*}{2.} & Usia & & \\
\hline & 21-25 tahun & 15 & 60 \\
\hline & 26-30 tahun & 7 & 28 \\
\hline & 31-35 tahun & 3 & 12 \\
\hline \multirow[t]{3}{*}{3.} & Program Studi & & \\
\hline & Manajemen & 18 & 72 \\
\hline & Akuntansi & 7 & 28 \\
\hline \multirow[t]{3}{*}{4.} & Status Mahasiswa & & \\
\hline & Non regular & 22 & 88 \\
\hline & Regular & 3 & 12 \\
\hline
\end{tabular}

Sumber : Data primer diolah (2020) 


\section{Analisis Uji Friedman}

Uji Friedman merupakan suatu pengujian dengan melihat rank mean pada setiap variabel. Berdasarkan tabel 4, persepsi mahasiswa terhadap 5 (lima) pertanyaan pada masing-masing item pertanyaan penilaian mahasiswa STIENI terhadap setiap atribut pembelajaran sistem daring online untuk setiap atribut yang paling penting tertinggi yaitu metode pembelajaran sebesar 3,52. Hal ini disebabkan, pada mata kuliah matematika diperlukannya pemahaman dan penalaran secara khusus penyampaian setiap materi agar mahasiswa dapat mengerti isi pemateri yang disampaikan secara online.

Untuk urutan kedua adalah pelayanan dalam pembelajaran dinilai oleh mahasiswa penting sebesar 3,48. Hal ini dikarenakan, pada mata kuliah matematika diperlukan sebuah pelayanan yang baik dari tenaga pendidikan agar pesan yang disampaikan oleh tenaga pendidikan kepada mahasiswanya dapat tersampaikan dengan baik. Sedangkan untuk yang terendah adalah kualitas dalam pembelajaran dan tenaga pendidikan dinilai cukup penting sebesar 1,50. Untuk tenaga pendidikan dan kualitas dalam pembelajaran mahasiswa STIENI menganggap cukup penting, hal ini dikarenakan mahasiswa STIENI menilai bahwa untuk mata kuliah matematika, atribut tersebut tenaga pengajar harus memiliki kualitas dari tenaga pendidikan maupun kualitas materi yang ajarkan, mengingat matematika merupakan mata kuliah yang memerlukan pelatihan yang ekstra.

Tabel 4.

Hasil Analisis Persepsi Mahasiswa STIENI terhadap Atribut.

\begin{tabular}{lc}
\multicolumn{1}{c}{ Atribut } & Mean Rank \\
\hline Metode pembelajaran & 3,52 \\
\hline Kualitas dalam pembelajaran & 1,50 \\
\hline Tenaga pendidikan & 1,50 \\
\hline Pelayanan dalam pembelajaran & 3,48 \\
\hline
\end{tabular}

Sumber : Data diolah dengan menggunakan Program SPSS 16,00 (2020)

\section{Uji Signifikansi Chi-Square Atribut}

Uji Signifikansi Chi-Square digunakan untuk mengetahui secara keseluruhan atribut pembelajaran sistem daring secara online apakah berpengaruh secara signifikansi atau tidak. Berdasarkan hasil uji signifikansi terhadap atribut secara keseluruhan untuk nilai Chi-Square sebesar 64,948 dengan $\mathrm{df}=3$ (tiga) disimpulkan Tolak $\mathrm{H}_{0}$, terima $\mathrm{H}_{1}$ artinya terdapat perbedaan persepsi mahasiswa STIENI terhadap penilaian berbeda pada setiap atribut pembelajaran sistem daring secara online pada mata kuliah matematika. Sehingga dapat disimpulkan bahwa mahasiswa STIENI menilai setiap atribut pembelajaran sistem daring secara online memiliki sikap yang sangat berbeda-beda terhadap tingkat kepentingan pada masing-masing indikator. 


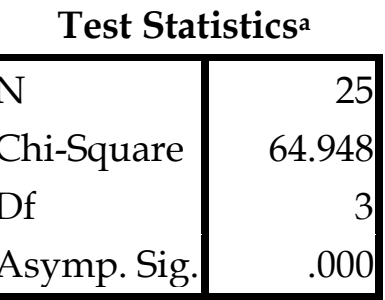

a. Friedman Test

Gambar 1. Hasil Uji Chi Square

Sumber : Data Primer Diolah (2020)

\section{Customer Satisfaction Indeks (CSI)}

Customer Satisfaction Indeks digunakan untuk mengetahui tingkat kepuasan pada setiap atribut pembelajaran sistem daring online. Berdasarkan tabel 5, hasil kepuasan mahasiswa STIENI terhadap atribut pembelajaran sistem daring secara online pada mata kuliah matematika adalah cukup puas sebesar 65\%. Hal ini dikarenakan untuk pembelajaran sistem daring secara online, diperlukan sikap kerjasama dalam menerapkan sistem pembelajaran sistem daring secara online sehingga dapat meningkatkan mutu pada setiap atribut dalam komponen penilaian yang baik dalam sistem pembelajaran daring secara online, baik antara mahasiswa STIENI dengan tenaga pendidikan. Untuk masing-masing atribut pada tingkat kepuasan, nilai yang tertinggi yaitu tenaga kependidikan sebesar 2,8, untuk posisi kedua yaitu metode pembelajaran dan pelayanan dalam pembelajaran sebesar 2,6, dan posisi terakhir yaitu kualitas pembelajaran sebesar 2,4 . Untuk tingkat kepentingan pada masing-masing atribut, nilai yang tertinggi yaitu tenaga kependidikan sebesar 2,8. Untuk posisi kedua yaitu metode pembelajaran dan pelayanan dalam pembelajaran sebesar 2,6. dan untuk posisi terendah adalah kualitas pembelajaran sebesar 2,4. Untuk tingkat kepentingan pada setiap atribut mahasiswa STIENI menilai sangat penting sebesar $100 \%$. Hal ini dikarenakan Mahasiswa STIENI menganggap bahwa kepentingan setiap atribut dalam penilaian sangat penting.

Tabel 5.

Hasil Kepuasan Mahasiswa Terhadap Pembelajaran Sistem Daring Secara Online

\begin{tabular}{lccccc}
\hline \multirow{1}{*}{\multicolumn{1}{c}{ Atribut }} & & & & & \\
& MSS & MIS & TKI & WS & WF \\
\hline Metode Pembelajaran & 2,6 & 2,6 & 100 & 0,65 & 0,250 \\
\hline Kualitas pembelajaran & 2,4 & 2,4 & 100 & 0,55 & 0,230 \\
\hline Tenaga Pendidikan & 2,8 & 2,8 & 100 & 0,75 & 0,269 \\
\hline Pelayanan dalam pembelajaran & 2,6 & 2,6 & 100 & 0,65 & 0,250 \\
\hline Total & 10,4 & 10,4 & & 2,6 & \\
\hline CSI & & & 65 & & \\
\hline
\end{tabular}

Sumber : Data primer diolah, (2020)

\section{Pembahasan}

\section{Persepsi Mahasiswa STIENI Berdasarkan Pada Setiap Atribut}

Hasil pengujian Friedman menunjukkan bahwa penilaian pada atribut berdasarkan urutan paling penting yang sangat berbeda-beda yaitu untuk posisi pertama 
yaitu metode pembelajaran, diurutan kedua yaitu pelayanan dalam pembelajaran, dan diurutan terakhir terdapat kualitas pembelajaran dan tenaga pendidikan. Hal ini dikarena mahasiswa STIENI menilai metode pembelajaran sangat penting dirasakan dalam pembelajaran sistem daring secara online pada pelajaran matematika sangat berbeda dan memiliki tingkat kerumitan tersendiri dibandingkan dengan mata kuliah lainnya. Oleh karena itu,diperlukan sikap interaktif antara tenaga pendidikan dengan mahasiswa. Metode pembelajaran yang mudah apabila dilakukan dengan tatap muka secara langsung sehingga mahasiswa STIENI dapat mengerti dengan bertanya secara langsung pada mata kuliah matematika. Menurut Sudjana, (2009) berpendapat ada beberapa faktor yang mempengaruhi metode pembelajaran yang efektif yaitu guru tidak berinovasi, rendahnya antusias mahasiswa dalam proses belajar mengajar, kondisi lingkungan, dan sangat rendah media pembelajaran.

Untuk pelayanan dalam pembelajaran, mahasiswa STIENI menganggap pada atribut tersebut adalah penting dirasakan dalam pembelajaran sistem daring secara online. Hal ini dikarenakan pelayanan dalam pembelajaran pada mata kuliah matematika sangat diperlukan mengingat mata kuliah matematika memerlukan metode pembelajaran yang extra dalam mempelajarinya, sehingga adanya bimbingan yang intens dalam setiap kali pertemuan dalam online. Hal ini sejalan dengan penelitian dari Ningsih, et al (2018) bahwa pelayanan yang berkualitas sangat baik dapat berpengaruh sikap siswa yang puas terhadap proses belajar mengajar.

Sedangkan untuk, kualitas pembelajaran dan tenaga pendidikan, mahasiswa STIENI menganggap bahwa kedua atribut tersebut cukup penting dirasakan dalam pembelajaran sistem daring secara online, hal ini dikarenakan dalam pembelajaran sistem daring secara online, mahasiswa dapat perlakuan dengan baik seperti halnya dengan sistem pembelajaran secara langsung dan tatap muka. Hal ini sejalan dengan pendapat dari Marhaeni (2007) yaitu konstruksi pengetahuan terjadi melalui proses interaksi sosial bersama orang lain yang lebih mengerti dan paham akan pengetahuan tersebut. Ada 3( tiga) macam gaya belajar yang diakomodasi oleh lingkungan sehingga menghasilkan proses pembelajaran dengan baik yaitu visual, auditori, dan kinestetik (Eudoxie, 2011). Menurut Turmudi, (2008) mengatakan bahwa matematika dipandang sebagai dua hal aktivitas interaktif dan aktivitas konstruktif.

\section{Analisis Persepsi Mahasiswa STIENI Berdasarkan Pengujian Serempak}

Hasil pengujian Uji Chi-Square mempunyai pengaruh secara signifikan terhadap atribut pembelajaran sistem daring secara online p-value 0,000 $<0,05$ dengan Uji Chi-Square sebesar 64,948. Artinya terdapat perbedaan persepsi mahasiswa STIENI terhadap penilaian atribut pembelajaran sistem daring online pada mata kuliah matematika. Menurut Handayani dan Nurwidawati, (2013) menjelaskan ada 4 (empat) faktor yang mempengaruhi persepsi manusia yaitu : faktor requirement, set, relation, dan value system. Relation artinya hubungan seseorang mempersepsikan dengan tidak hanya menangkap seluruh yang dirangsang tetapi difokuskan terhadap satu atau lebih dari objek yang sama. Set merupakan suatu harapan seseorang yang timbul dari rangsangan yang muncul. Requirement adalah segala sesuatu yang dibutuhkan oleh manusia yang akan mempengaruhi persepsi tersebut. Sedangkan value system merupakan suatu sistem yang mempunyai nilai manusia sehingga mempengaruhi persepsi tersebut. 


\section{Analisis Kepuasan Mahasiswa STIENI Pada Atribut}

Hasil kepuasaan mahasiswa STIENI terhadap setiap atribut pembelajaran sistem daring secara online adalah cukup puas sebesar 65,00. Artinya mahasiswa STIENI menilai bahwa sistem pembelajaran sistem daring secara online belum begitu sangat puas jika dibandingkan pembelajaran secara langsung. Hal ini sejalan dengan penelitian Firman dan Rahman, (2020) menjelaskan mahasiswa merasa puas dikarenakan fleksibilitas pelaksanaan perkuliahan. Sehingga mahasiswa tidak tertekan oleh waktu sesuai dengan jadwal dan tempat dimana mereka selalu menjalankan perkuliahan. Kepuasan merupakan suatu ungkapan perasaan seorang yang timbul rasa puas yang sesuai dengan harapan.

\section{Kesimpulan}

Berdasarkan hasil penelitian dapat disimpulkan yakni :

1. Persepsi mahasiswa STIENI terhadap atribut pembelajaran sistem daring secara online pada mata kuliah matematika adalah atribut yang paling penting tertinggi yaitu metode pembelajaran sebesar 3,52, diurutan kedua penting yaitu pelayanan dalam pembelajaran sebesar 3,48, sedangkan posisi terakhir berdasarkan atribut cukup penting yaitu kualitas pembelajaran dan tenaga pendidikan sebesar 1,50. Untuk penilaian persepsi mahasiswa STIENI secara seluruhan pada atribut pembelajaran sistem daring secara online dengan menggunakan uji Chi-Square diperoleh 64,948 dengan tingkat signifikansi 0,000<0,05 adalah ada perbedaan persepsi mahasiswa STIENI terhadap penilaian pada setiap atribut pembelajaran sistem daring secara online pada mata kuliah matematika. Hal ini dapat diartinya mahasiswa STIENI menilai bahwa pembelajaran sistem daring secara online pada masing-masing atribut memiliki penilaian yang berbeda-beda.

2. Untuk tingkat kepuasan mahasiswa STIENI terhadap pembelajaran sistem daring secara online adalah cukup puas sebesar $65 \%$.

\section{Saran}

Terkait dengan hasil penelitian, dapat disarankan adalah :

1. Untuk mempelancar sistem daring secara online, kampus diharapkan memberikan fasilitas kuota gratis agar meringannya mahasiswa dalam melakukan perkuliahan secara online.

2. Penelitian ini hanya sebagian cangkupan yakni mahasiswa STIENI yang sedang mengampuh mata kuliah matematika. Oleh karena itu, bagi peneliti selanjutnya, diharapkan dapat memperluas cakupan penelitian khususnya dalam hal pengambilan sampel penelitian agar hasilnya dapat digeneralisasi.

\section{Daftar Pustaka}

Dickson, D., Christin, S., \& Owen, Hargie. (2004). Social Skillss in Interpersonal Communication. London:Third Edition. Phychology Press.

Eudoxie, G. D. (2011). Learning Styles Among Students In An Advanced Soil Management Class: Impact On Student's Performance. 137-144. 
Fathuroman, A. (2011). Pengaruh Pengembangan Model Pembelajaran E-Learning Terhadap Prestasi Belajar Mahasiswa Fakultas Kedokteran Universitas Muhammadiyah Semarang. Publish Tesis, Universitas Muhammadiyah Semarang, Semarang.

Firman, \& Rahman, S.R. (2020). Pembelajaran Online Di Tengah Pandemi Covid-19. Jurnal. Indonesian Journal Of Education Science (IJES). 02 (02).

Gikas, J., \& Grant, M. M. (2013). Mobile computing devices in higher education: Student perspectives on learning with cellphones, smartphones $\mathcal{E}$ social media. Internet and Higher Education. https://doi.org/10.1016/j.iheduc.2013.06.002.

Handayani, F., dan Nurwidawati, D. (2013). Hubungan Self efficacy Dengan Prestasi Belajar Siswa. Akselerasi. Surabaya : UNESA. Surabaya.

Kamus Besar Bahasa Indonesia. (2020). Arti Kata Atribut. https://kbbi.web.id/atribut.html. Diunduh pada tanggal 10 Juni 2020.

Kementrian Pendidikan dan Kebudayaan. (2012). Undang-Undang Republik Indonesia Nomor 12 Tahun2012 Tentang Pendidikan Tinggi. http://kemendikbud.go.id/kemdikbud/sites/default/files/UPPT-12-thn-2012.pdf. Diunduh pada tanggal 10 Juni 2020.

Marhaeni, I. (2007). Pembelajaran Inovatif dan Asesmen Otentik dalam Rangka Menciptakan Pembelajaran yang Efektif dan Produktif. Makalah Dalam Penyusunan Kurikulum dan Pembelajaran Inovatif Di Universitas Udayana. Bali.

Ningsih, D. A., Ali, I., dan Teguh, T. (2018). Hubungan Persepsi Tentang Kualitas Dan Pelayanan Pendidikan Dengan Kepuasan Orang Tua Siswa Sekolah Menengah Kejuruan Negeri. Jurnal Administrasi dan Manajemen Pendidikan. Vol. 1 (2).

Nitisusastro, M. (2013). Perilaku Konsumen dalam Perspektif Kewirausahaan. Bandung: Penerbit Alfabeta.

Pannen, P. (2016). Kebijakan Pendidikan Jarak Jauh dan E-learning di Indonesia. Jurnal Kemenristek Dikti.

Putri, S.L. (2018). Analisa Persepsi Konsumen Terhadap Atribut Desa Wisata Di Kabupaten Sleman. Unpublished Skripsi, Institut Pertanian Bogor, Bogor.

Riadi, E. 2016. Statistika Penelitian (Analisis Manual dan IBM SPSS). Yogyakarta:CV. Andi.

Robbin, S.P. (2003). Perilaku Organisasi. Jakarta: Indeks.

Siagian, G. Y. H. (2017). Sikap Konsumen Terhadap Keputusan Pembelian Bandeng Duri Lunak Di Toko Bandeng Juwana Kota Semarang. Publish Tesis, Universitas Diponegoro, Semarang. 
M. D. (2016). Kemampuan Koneksi Matematik Dalam Pembelajaran Matematika. Journal of Mathematics Education and Science. Vol. 2(1).

Slamento. (2003). Belajar dan Faktorf-aktor yang Mempengaruhinya. Jakarta: PT. Rineka Cipta.

Sudjana, N., dan Rivai, A. (2009). Penilaian Hasil Belajar Mengajar (Online). Bandung; Remaja Rosdakarya.

Turmudi. (2008). Lanadasan Filsafat dan Teori Pembelajaran Matematika (Berparadigma Eksploratif dan Investigatif). Jakarta: Leuser Cipta Pustaka.

Widodo, S.M., Joko, S. (2018). Metode Customer Satisfation Index (CSI) untuk Mengetahui Pola Kepuasan Pelanggan Pada E-Commerce Model Business to Customer. Jurnal Informatika UPGRIS. Vol. 4(1).

Youtube, K. (2020). Data Covid-19 Pada Bulan Maret, April dan Mei. [Diakses pada tanggal 13 Juni 2020 pukual 12.00 WIB]. 